\title{
O uso de antibióticos na endodontia
}

\section{The use of antibiotics in endodontia}

Segura-egea JJ., Gould K., Şen BH., Jonasson P., Cotti E., Mazzoni A., Sunay H., Tjäderhane L., Dummer PM. Antibiotics in Endodontics: a review. Int Endod J. 2016 Dec 22. doi: 10.1111/ iej.12741.

Camila Soares Lopes' Leopoldo Cosme-Silva"

O uso excessivo de antibióticos e o aparecimento de bactérias resistentes são uma preocupação global. Essa preocupação também é importante em termos de microbiota e a utilização de antibióticos para lidar com as infecçõesdentárias. As infecçõesodontogênicas, incluindo infecções endodônticas, são provocadas por polimicrobianos que envolvem uma combinação de gram-positivos, gramnegativos, anaeróbios facultativos e bactérias anaeróbias estritas. A sensibilidade das bactérias da cavidade oral aos antibióticos está diminuindo gradualmente, e um número de linhagem resistente está sendo detectado, em particular Porphyromonas spp. e Prevotella spp.

Os antibióticos são coadjuvantes úteis em casos específicos, uma vez que contribuem para a prevenção da propagação da infecção. A escolha de um antibiótico específico é geralmente com base em tipos de bactérias mais comuns nos sítios de infecção. Portanto, o cirurgião dentista clínico deve identificar esses casos corretamente e prescrever os antibióticos de maneira correta. $\mathrm{O}$ uso de antibióticos sistêmicos em endodontia deve ser limitado a casos específicos, de modo a evitar a sua sobreprescrição. Eles podem ser utilizados como um coadjuvante no tratamento de patologias periapicais em pacientes com alguma debilidade sistêmica.

Pacientes imunocomprometidos são mais susceptíveis a complicações decorrentes de infecções endodônticas, portanto, os antibióticos devem ser considerados em pacientes com doenças sistêmicas e com imunidade comprometida, como pacientes com endocardite infecciosa, próteses de válvulas cardíacas ou com recente prótese articular.

Entre as drogas de escolha estão a classe da penicilina, que pode ser ou não combinada ao metronidazol. Essa combinação permite umamplo espectro deaçãoem bactérias aeróbias e anaeróbias, respectivamente. Outra associação é penicilina com o ácido clavulânico, que é indicado em pacientes que apresentem algum tipo de resistência prévia à penicilina. Em caso de alergia à penicilina, a clindamicina é a droga de escolha.

Portanto, o cirurgião dentista deve ficar atento ao quadro clínico do paciente e levar em consideração doenças sistêmicas e a imunidade do paciente e, assim, eleger corretamente uma droga. Além disso, o uso indiscriminado dos antibióticos acarreta resistência bacteriana, o que é prejudicial ao controle da infecção, podendo levar a problemas mais sérios. 
De um modo geral, percebe-se que as drogas mais utilizadas por endodontistas nos últimos anos continuam sendo as penicilinas combinadas com metronidazol ou ácido clavulânico, sem grandes possibilidades de acréscimo de novos medicamentos aplicáveis aos casos de infecção, visto que os agentes bacterianos encontrados mantêm-se sem novas agregações, apesar de possível resistência.

\section{Dados dos Autores}

\section{Camila Soares Lopes}

Mestranda em Ciências Odontológicas pela Universidade Federal de Alfenas. Alfenas/MG - Brasil.milasoares.odonto@gmail.com

\section{Leopoldo Cosme-Silva}

Mestre em Ciências Odontológicas pela Universidade Federal de Alfenas. Alfenas/MG - Brasil. leopoldocosme@gmail.com 